\section{EMBRYAIDDLE \\ Aeronautical University}

SCHOLARLY COMMONS

\section{International Journal of Aviation,} Aeronautics, and Aerospace

6-11-2015

\title{
Sustainability Reporting Practices of Group III U.S. Air Carriers
}

Lukas Rudari

Purdue University, Irudari@purdue.edu

Mary E. Johnson

Purdue University, mejohnson@purdue.edu

Follow this and additional works at: https://commons.erau.edu/ijaaa

Part of the Business Administration, Management, and Operations Commons, Business and Corporate Communications Commons, Business Intelligence Commons, Business Law, Public Responsibility, and Ethics Commons, Organizational Behavior and Theory Commons, and the Technology and Innovation Commons

\section{Scholarly Commons Citation}

Rudari, L., \& Johnson, M. E. (2015). Sustainability Reporting Practices of Group III U.S. Air Carriers. International Journal of Aviation, Aeronautics, and Aerospace, 2(2). https://doi.org/10.15394/ ijaaa.2015.1066

This Article is brought to you for free and open access by the Journals at Scholarly Commons. It has been accepted for inclusion in International Journal of Aviation, Aeronautics, and Aerospace by an authorized administrator of Scholarly Commons. For more information, please contact commons@erau.edu. 
Sustainability reporting is growing in importance in the U.S. and across the globe. Of the 100 largest companies by revenue in 41 countries, 71\% participated in sustainability reporting in 2013 (KPMG, 2013). The percentage of companies which included sustainability information in their annual reports was 51\% in 2012, up from 9\% in 2008 (KPMG, 2013). Sustainability is "now standard business practice worldwide" (KPMG, 2013, p. 10). In the transport sector, sustainability reporting has increased from 39\% in 2008 to 69\% in 2013 (KPMG, 2013). Because sustainability reporting has become prevalent across virtually all sectors, including transportation, the sustainability reporting practices of airlines are relevant and important. This research was guided by the following question: which major US airlines participate in sustainability reporting? The purpose of this study was to explore and understand the sustainability reporting practices of U.S. passenger and cargo airlines with total revenues exceeding \$1 billion, which the U.S Department of Transportation classifies as Group III air carriers (United States Department of Transportation [DOT], 2013).

Over the last decade, the topic of sustainability has gained some popularity in the aviation sector, mainly led by industry organizations, such as the International Civil Aviation Authority (ICAO), the International Air Transport Association (IATA) or the Air Transport Action Group (ATAG). This research paper was an exploratory study to determine the state of sustainability reporting among major U.S. airlines. The results of this study should enable the reader to better understand the current state of sustainability reporting practices in the population examined and enable researchers to develop future studies in aviation sustainability and sustainability reporting by identifying which airlines embraced sustainability reporting and which did not. Stebbin (2001) described the purpose of exploratory research as the need to "first observe the woods, then study the individual trees" (p. V).

Previous research about sustainability reporting has focused on subjects such as sustainability reporting practices of Fortune Global 250 companies or sustainability reporting practices in specific countries or geographic areas, such as Australia or Europe (e.g., Delbard, 2008; Frost, Jones, Loftus, \& Van Der Laan, 2005; Kolk, 2008). In the context of aviation, previous research has looked at quantitative aspects of sustainability of air transportation, carbon emission aspects of sustainability in aviation or general trends and issues of the subject of sustainability and aviation (Janić, 2007; Johnson \& Gonzalez, 2013; Upham, 2003). 


\section{Research Problem}

The role of business entities in the promotion of sustainable development has changed dramatically over the last decades. Widely known as the Triple Bottom Line (TBL) reporting approach, sustainability reporting among corporations has gained enormous popularity since the 1990s (Milne, \& Gray, 2011). Originally conceived by Elkington (1997), the TBL reporting approach recognized the need for businesses to take environmental, social and economic aspects of sustainability into consideration.

The aviation sector has been hesitant to embrace sustainability and sustainability reporting. With a delay of more than a decade, Upham (2003) and Janić (2007) were among the first to publish research about sustainability aspects of aviation. The rise in sustainability reporting in sectors other than aviation likely occurred earlier due to regulatory and societal attention on the issue (Kolk, 2004). It is expected that the U.S Environmental Protection Agency (EPA) will publish an "endangerment finding" for greenhouse gas emissions caused by aircraft in June 2015 (Saiyid, 2015). Endangerment findings are usually a precursor to regulatory action (EPA, n.d.). It is conceivable that airlines will soon have to follow this trend of measuring and reporting environmental performance in the form of sustainability reporting. Of the transportation companies issuing sustainability reports, regulatory risk was the most frequently indicated reason for participating (KPMG, 2013).

In light of these recent developments, the paper identified which airlines participated in sustainability reporting, and therefore, may be better prepared for pending legislative action and which airlines did not participate and may be at risk of being not as prepared for future regulatory mandates. This research sought to answer the following research question and sub-questions:

Which major U.S. airlines participate in sustainability reporting?

(a) Which major U.S airlines use the Global Reporting Initiative framework?

(b) Which major U.S. airlines participate in the Carbon Disclosure Project questionnaires?

\section{Theoretical framework}

An exploratory research framework was chosen for this study, as no extensive research existed on sustainability reporting practices of major U.S. airlines. Jaeger and Halliday (1998) described the goal of exploratory research as

gaining “...new insights, from which new hypothesis might be developed” (p. S64). Exploratory research is characterized by the lack of specific verifiable research hypotheses. Instead, this exploratory study aimed to enable other researchers to 
gain, as Jaeger and Halliday (1998) suggested, new insights and open the subject up for discussion and further research. Although traditionally used in the social sciences, an observational exploratory research framework was selected to explore the topic of sustainability reporting among air carriers as it seemed appropriate for the nature of the problem, which is the lack of attention and research in this area.

\section{Method}

In line with the exploratory nature of this study, the methodology was primarily based on descriptive and observational data acquisition from various data sources to explore the state of sustainability reporting practices among major U.S. air carriers. A major section of this study was dedicated to the presentation of the concept of sustainability in the aviation sector in order to introduce the reader to the nature of the concept. Thereafter, the most frequently used sustainability reporting frameworks and their applicability to the aviation industry were investigated.

Information concerning the participation in sustainability was obtained for air carriers in the calendar year 2013, based on the Sustainability Disclosure Database (Global Reporting Initiative [GRI], 2015b), which tracked sustainability reports published by companies worldwide. Sustainability reports were published once a year, concurrently with a company's annual report. KPMG, a global business consulting firm, recommended that corporate boards begin integrated reporting of financial and sustainability (KPMG, 2013). The database classified sustainability reports as "GRI Reports" if the company's sustainably reports contained a GRI Content Index, as "GRI - Referenced" if the report referred to GRI guidelines without having a GRI Content Index and as "Non-GRI" if the report did not refer to the GRI guidelines at all (GRI, 2015). For the purposes of this study, the same classifications were used to answer part (a) of the sub-research questions.

For participation in the CDP, sub-research question (b), the CDP database available on the organization's website was used to evaluate if any of the air carriers participated in one or more CDP initiatives for the calendar year 2014. The disclosure score and the performance band ranking, if available, was queried and recorded in a table. Similar to sustainability reports, CDP questionnaires were submitted once a year.

Twenty air carriers qualified as Group III air carriers in the calendar year 2014. Five of these airlines were excluded from this study as these airlines have either gone out of business or have merged with other air carriers. For the purposes of this study, the remaining 15 carriers were organized into four groups. The first group was labeled legacy passenger carriers, which included American Airlines, Delta Air Lines, and United Airlines. The second group was labeled national 
passenger carriers, which included Alaska Airlines, Frontier Airlines, Hawaiian Airlines, jetBlue, Southwest Airlines, Spirit Airlines and Virgin America. The sole regional carrier in the regional passenger carrier group under consideration in this study was SkyWest. The cargo carriers Atlas Air, Federal Express, Kalitta Air LLC and UPS were members of the cargo carrier group (DOT, 2013).

\section{Literature review}

To enable the reader to better understand the state of sustainability in the aviation industry, the literature review focused on the origins of the sustainability movement in the air transportation sector, followed by a review of the two most frequently used sustainability reporting frameworks, the Global Reporting Initiative and the Carbon Disclosure Project.

\section{The sustainability movement in the air transport sector}

Traditionally, the sustainability movement in the air transport sector has focused on environmental aspects, such as carbon dioxide emissions, noise pollution or biofuel usage (Upham, 2003). In its landmark Aviation and the Global Atmosphere report published in 1999, the Intergovernmental Panel on Climate Change (IPCC) assessed the effects of aviation on climate change. The report was the first IPCC publication for a specific industry, demonstrating the urgency of the topic (IPCC, 1999). A few years later in 2003, the U.S. Federal Aviation Administration (FAA) launched its "NextGen" initiative with the aim of transforming U.S. airspace through operational improvements addressing the dimensions of safety, environment and energy efficiency (U.S. Federal Aviation Administration [FAA], 2015a). National Airspace System-Wide Energy Efficiency performance, which the FAA defined as estimated fuel burn in kilograms per revenue ton kilometer, showed some improvement in energy efficiency as shown in Figure 1. In 2005, 0.359 kilograms of fuel per revenue ton kilometer were burned, compared to 0.328 kilograms in 2013 (FAA, 2015b).

Figure 2 showed that the energy efficiency as measured in Available Seat Miles (ASM) per gallon of fuel for domestic flights on U.S. air carriers exceeding revenues of $\$ 20$ million annually has notably improved over the last 12 years (DOT, 2015). Overall fuel efficiency was at 51 ASM per gallon in 2002. This value has increased to 67 ASM per gallon in 2014, a fuel efficiency improvement of $2.2 \%$ per year on average or $31 \%$ in total. 


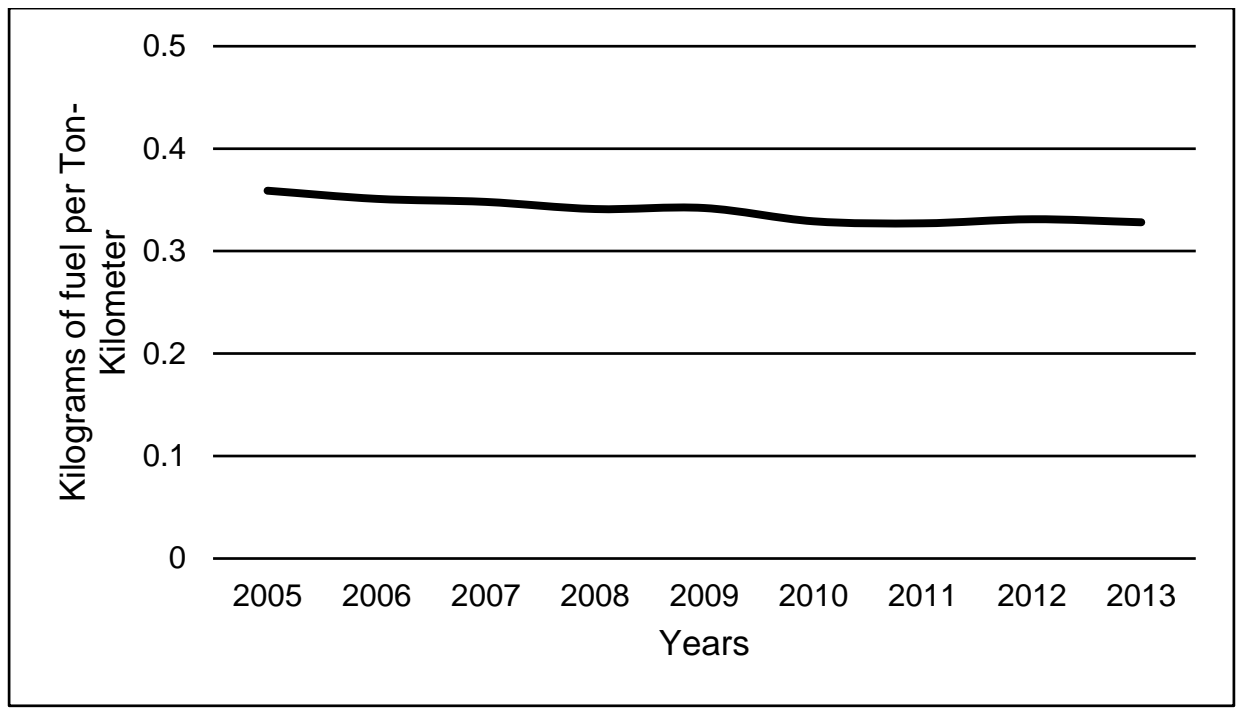

Figure 1. The change in kilograms of fuel burn per ton-kilometer for U.S. airlines from 2005 to 2013. Data obtained from U.S. FAA (FAA, 2015b).

Since 2003, a number of aviation industry associations, such as ATAG or IATA have published guidance material on sustainability aspects of the air transport sector, expanding the scope of the sustainability movement to economic and social dimensions. The most prominent work of ATAG was the Aviation Benefits Beyond Borders report, which was structured in accordance with the TBL philosophy using three sub-headings: economic growth, social development and environmental efficiency (Air Transport Action Group, 2014).

\section{The advent of standardized sustainability reporting frameworks}

Following the rise of the sustainability movement, a number of voluntary reporting initiatives have been established to assist companies worldwide in publishing sustainability aspects of an organization's business practices. Two of the most frequently used reporting frameworks were provided by the Carbon Disclosure Project (CDP) and the Global Reporting Initiative (GRI) (GreenBiz, 2013). The 2013 KPMG Survey of Corporate Responsibility Reporting found that about $78 \%$ of 4,100 companies surveyed in 41 countries refer to GRI in their corporate responsibility or sustainability reports (KPMG, 2013). 


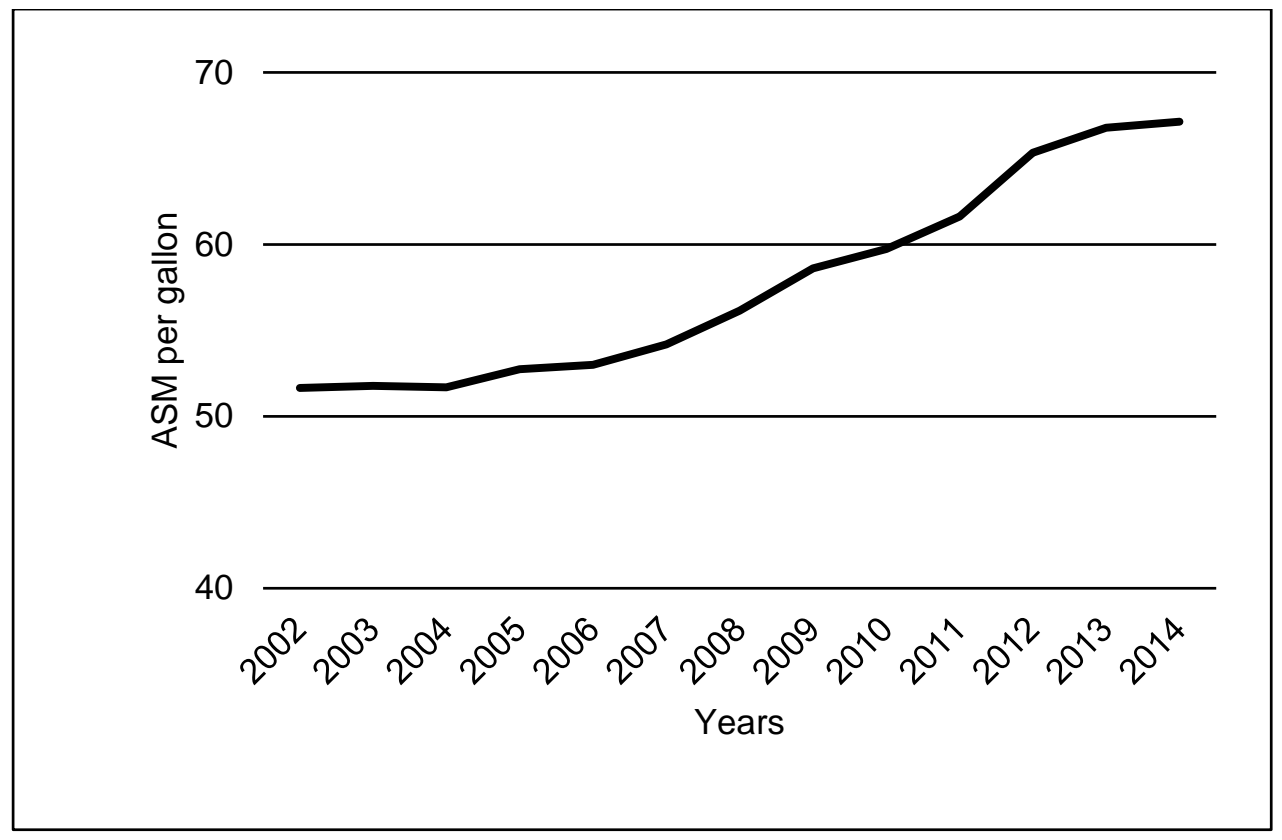

Figure 2. The change in number of Available Seat Miles (ASM) per gallon of fuel on domestic flights for U.S. air carriers exceeding revenues of \$20 million per year. Data obtained from the U.S. Department of Transportation (DOT, 2015).

\section{The Global Reporting Initiative}

The Global Reporting Initiative (GRI) is a sustainability reporting framework with the aim of spreading the practice of sustainability reporting to companies and organizations worldwide (GRI, 2015a). Formally established in 2002, the GRI provides companies with a voluntary sustainability reporting framework to publish their performance on economic, environmental, social and organizational governance aspects of sustainability (GRI, 2015a). These guidelines are widely used globally, with $82 \%$ of the world's largest companies using the GRI reporting guidelines (KPMG, 2013).

GRI defined fundamental principles for preparing a sustainability report. For determination of relevant report content, the four principles of materiality, stakeholder inclusiveness, sustainability context and completeness should be applied. GRI mentioned the principles of balance, comparability, accuracy, timeliness, clarity and reliability for report quality (GRI, 2014).

Companies seeking GRI G4 compliance, the fourth revision of this sustainability reporting framework, can choose between a core option, containing essential reporting elements only, and a comprehensive option, which requires 
more extensive reporting (GRI, 2013a). For both options, companies have to report or reference all items contained in the General Standard Disclosure sections. Depending on the option chosen, companies have to partially or completely report or reference the items described in the Specific Standard Disclosures section.

Table 1 shows all topic areas of the General and Specific Standard Disclosures sections. Companies may also have to comply with sector specific disclosures, currently available for airport operators, construction and real estate, electric utilities, event organizers, financial services, food processing, media, mining and metals, NGOs and oil and gas industry.

Table 1

Overview of core GRI G4 components

\begin{tabular}{ll}
\hline General Standard Disclosures & Specific Standard Disclosures \\
\hline Strategy and Analysis & Disclosures on Management Approach \\
Organizational Profile & Economic Indicators \\
Identified Material Aspects and & Environmental Indicators \\
Boundaries & Social Indicators \\
Stakeholder Engagement & \\
Report Profile & \\
Governance & \\
Ethics and Integrity & \\
\hline
\end{tabular}
Note. Adapted from "G4 Sustainability Reporting Guidelines” by GRI, 2013a.

GRI and the airline industry. GRI published a list of areas identified as relevant for stakeholders of airlines, which were grouped into economic, environmental, social and "other" topics. For economic sustainability, GRI identified the topic of carbon offsetting and direct/indirect economic benefits as particularly relevant for airlines. In the area of environmental sustainability, the topics identified by GRI include material sourcing or use, renewable/alternative energy sources, energy efficiency initiatives, air quality, emissions to air, greenhouse gas emissions and noise. For social sustainability aspects, GRI mentioned labor conditions, labor management relations, cabin personnel health/safety, cabin air quality, unlawful sex tourism, persons with special needs access to services/facilities, emergency preparedness and fleet technological improvement. As "other" topics, corporate governance and sourcing strategy for aircraft/components were mentioned (GRI, 2013b). Table 2 highlights all topic areas as well as sub topics if applicable. 
Table 2

GRI Guidance material for the airline sector

\begin{tabular}{|c|c|c|}
\hline $\begin{array}{l}\text { Sustainability } \\
\text { Category }\end{array}$ & Topic & Topic Specification \\
\hline \multirow{3}{*}{ Economic } & Carbon Offsetting & N/A \\
\hline & \multirow{2}{*}{ Economic direct and indirect benefits } & $\begin{array}{l}\text { Employment, accessibility and } \\
\text { mobility }\end{array}$ \\
\hline & & Jobs and economic multiplier effect \\
\hline \multirow{9}{*}{ Environmental } & \multirow{2}{*}{$\begin{array}{l}\text { Materials sourcing and use } \\
\text { Renewable/alternative energy } \\
\text { sources }\end{array}$} & Plastic products \\
\hline & & Biofuel \\
\hline & \multirow{2}{*}{ Energy efficiency initiatives } & Fuel use efficiency \\
\hline & & Weight of flight load \\
\hline & \multirow{2}{*}{$\begin{array}{l}\text { Air quality } \\
\text { Emissions to air }\end{array}$} & Airports \\
\hline & & Aircraft \\
\hline & Emissions to air - GHG emissions & $\begin{array}{l}\text { Management and reduction } \\
\text { strategies }\end{array}$ \\
\hline & $\begin{array}{l}\text { Emissions to air - GHG emissions } \\
\text { and other emissions }\end{array}$ & $\begin{array}{l}\text { Management and reduction } \\
\text { strategies }\end{array}$ \\
\hline & Noise & Aircraft and components \\
\hline \multirow{8}{*}{ Social } & Labor conditions & $\begin{array}{l}\text { Workforce turnover and } \\
\text { restructuring }\end{array}$ \\
\hline & Labor management relations & Strikes and/or lock-outs \\
\hline & Cabin personnel health and safety & Risk assessment and mitigation \\
\hline & Cabin air quality & $\begin{array}{l}\text { On-board health and safety } \\
\text { conditions }\end{array}$ \\
\hline & Unlawful sex tourism & $\begin{array}{l}\text { Human trafficking risks and child } \\
\text { abuse }\end{array}$ \\
\hline & $\begin{array}{l}\text { Persons' with special needs access to } \\
\text { services and facilities }\end{array}$ & $\begin{array}{l}\text { Travelers with disabilities and } \\
\text { medical conditions }\end{array}$ \\
\hline & Emergency preparedness & N/A \\
\hline & Fleet technological improvement & Noise, energy efficiency, emissions \\
\hline \multirow{2}{*}{ Other } & Corporate governance & $\begin{array}{l}\text { Gender participation on governance } \\
\text { bodies }\end{array}$ \\
\hline & $\begin{array}{l}\text { Sourcing strategy for aircraft and } \\
\text { components }\end{array}$ & $\begin{array}{l}\text { Sourcing standards on aircraft } \\
\text { energy efficiency }\end{array}$ \\
\hline
\end{tabular}

Note. Adapted from "Sustainability Topics for Sectors: What do stakeholders want to know?" by GRI, 2013 b.

\section{The Carbon Disclosure Project}

The Carbon Disclosure Project (CDP) is a nonprofit organization based in London, United Kingdom. Launched in 2000, the purpose of CDP is to raise investor awareness for climate change and address environmental concerns with companies. As of 2014, CDP collaborated with 4,500 companies and more than 800 institutional investors holding a total of $\$ 95$ trillion in assets (CDP, 2014). 
CDP gathers data about environmental performance of a company by analyzing questionnaires submitted by companies sent on behalf of institutional investors. More specifically, CDP focuses on a company's environmental performance in regard to climate change, deforestation risks, water use and supply chain management. Apart from these four questionnaires, a separate questionnaire is available for municipalities wishing to participate in the CDP. Initially, CDP sent out questionnaires to Fortune 500 companies only. The scope of CDP was eventually expanded to include more companies. Participation in CDP is voluntary and companies may choose to submit questionnaires for one or more of the four programs (CDP, 2014).

CDP and the airline industry. The Carbon Disclosure Project did not publish specific guidance material for the airline industry. In 2010, a report focusing on the disclosure practices of the transport sector in general was published by the CDP. The report found that only $36 \%$ of companies in the transportation sector have defined emission targets, compared to an average of 51\% across non-transport companies. The report furthermore suggested that "... air transport leads the way on setting targets surface transport lags behind" (CDP, 2010, p. 19).

\section{Alignment of CDP and GRI}

CDP, as opposed to the GRI, provides a disclosure score and a performance band rating to participating organizations in its Climate Change questionnaire (CDP, 2014). Both GRI and CDP aim to provide companies with a standardized method to disclose performance data on similar dimensions of sustainability. Recognizing the need for collaboration between GRI and CDP, a Memorandum of Understanding was signed in May 2013 to further the alignment of both reporting frameworks. The goal of the collaboration was to avoid duplication of disclosure efforts and to achieve synergy effects for companies willing to participate in both reporting initiatives (GRI, 2014).

\section{Results}

According to GRI, eight out of fifteen of Group III air carriers (53\%) published sustainability related information, either as separate report or as part of their annual report as shown in Table 3. Seven out of eight of these carriers (88\%) referenced the GRI framework in their sustainability reports. According to data obtained from CDP, six out of fifteen carriers (40\%) participated in one or more CDP questionnaires, as shown in Table 4. There were notable differences between the three groups of carriers. While all three legacy carriers published sustainability reports and participated in the CDP, two out of four cargo carriers did so. Finally, three out of eight national carriers published sustainability reports, all of which referenced the GRI framework in their sustainability reports. SkyWest, the only 
regional carrier in this study, did not publish a sustainability report nor participated in CDP.

Table 3

Overview of sustainability reporting practices of Group III U.S. air carriers

\begin{tabular}{|c|c|c|c|c|}
\hline Group & Carrier & Sustainability report & GRI & CDP \\
\hline \multirow{3}{*}{$\begin{array}{l}\text { Legacy } \\
\text { passenger carrier }\end{array}$} & American Airlines & Yes & No - Non GRI & Yes \\
\hline & Delta Air Lines & Yes & Yes - GRI G3.1 & Yes \\
\hline & United Airlines & Yes & Yes - GRI G3 & Yes \\
\hline \multirow{7}{*}{$\begin{array}{l}\text { National } \\
\text { passenger } \\
\text { carriers }\end{array}$} & Alaska Airlines & Yes & Yes - GRI G4 & No \\
\hline & Frontier Airlines & No & N/A & No \\
\hline & Hawaiian Airlines & No & N/A & No \\
\hline & JetBlue & Yes & Yes - GRI G4 & No \\
\hline & Southwest Airlines & Yes & Yes - GRI G3 & Yes \\
\hline & Spirit Airlines & No & N/A & No \\
\hline & Virgin America & No & N/A & No \\
\hline $\begin{array}{l}\text { Regional } \\
\text { passenger } \\
\text { carriers }\end{array}$ & SkyWest & No & N/A & No \\
\hline \multirow{4}{*}{ Cargo carriers } & Atlas Air & No & N/A & No \\
\hline & Federal Express & Yes & Yes - GRI G3.1 & Yes \\
\hline & Kalitta Air, LCC & No & N/A & No \\
\hline & UPS & Yes & Yes - GRI G4 & Yes \\
\hline
\end{tabular}

\section{Legacy carriers}

All three legacy carriers published sustainability reports and participated in at least one Carbon Disclosure Program questionnaire. Delta is the only legacy carrier to receive a disclosure score and placement in the performance band. The sustainability reports published by Delta Air Lines and United Airlines contained information related to GRI G3 guidelines. Delta Air Lines and United Airlines referenced GRI guidelines in their sustainability reports, while American Airlines did not.

American Airlines' 2012 Corporate Responsibility Report referred to GRI G3 guidelines (American Airlines Group, 2013). Subsequent reports, however, did not include any reference to GRI and were classified as "Non-GRI" by the Sustainability Disclosure Database (GRI, 2015b). American Airlines participated in CDP's Climate Change 2014 and Supply Chain 2014 questionnaires. While supply chain questionnaire scores were not disclosed to the public, the climate change questionnaire submitted by American Airlines to CDP was not scored, indicating that American Airlines did not provide the necessary information for scored questions (CDP, 2015). 
Table 4

Overview of CDP participation of Group III U.S. air carriers

\begin{tabular}{|c|c|c|c|c|}
\hline Group & Carrier & CDP questionnaire & $\begin{array}{l}\text { Disclosure } \\
\text { score }\end{array}$ & $\begin{array}{l}\text { Performance } \\
\text { band }\end{array}$ \\
\hline \multirow{5}{*}{$\begin{array}{l}\text { Legacy } \\
\text { passenger } \\
\text { carrier }\end{array}$} & American Airlines & Climate Change 2014 & Not Scored & Not Scored \\
\hline & American Airlines & $\begin{array}{l}\text { CDP Supply Chain } \\
2014\end{array}$ & Not Available & Not Available \\
\hline & Delta Air Lines & Climate Change 2014 & 93 & B \\
\hline & Delta Air Lines & $\begin{array}{l}\text { CDP Supply Chain } \\
2014\end{array}$ & Not Available & Not Available \\
\hline & United Airlines & Climate Change 2014 & Not Scored & Not Scored \\
\hline \multirow{8}{*}{$\begin{array}{l}\text { National } \\
\text { passenger } \\
\text { carriers }\end{array}$} & Alaska Airlines & No & N/A & N/A \\
\hline & Frontier Airlines & No & N/A & N/A \\
\hline & Hawaiian Airlines & No & N/A & N/A \\
\hline & JetBlue & No & N/A & N/A \\
\hline & $\begin{array}{l}\text { Southwest } \\
\text { Airlines }\end{array}$ & Climate Change 2014 & 89 & B \\
\hline & $\begin{array}{l}\text { Southwest } \\
\text { Airlines }\end{array}$ & $\begin{array}{l}\text { CDP Supply Chain } \\
2014\end{array}$ & Not Available & Not Available \\
\hline & Spirit Airlines & No & N/A & N/A \\
\hline & Virgin America & No & N/A & N/A \\
\hline $\begin{array}{l}\text { Regional } \\
\text { passenger } \\
\text { carriers }\end{array}$ & SkyWest & No & N/A & N/A \\
\hline \multirow{7}{*}{$\begin{array}{l}\text { Cargo } \\
\text { carriers }\end{array}$} & Atlas Air & No & N/A & N/A \\
\hline & Federal Express & Climate Change 2014 & 90 & B \\
\hline & Federal Express & Forests 2014 & Not Scored & Not Scored \\
\hline & Kalitta Air, LCC & No & N/A & No \\
\hline & UPS & Climate Change 2014 & 100 & A- \\
\hline & UPS & Water 2014 & Not Scored & Not Scored \\
\hline & UPS & Forests 2014 & Not Scored & Not Scored \\
\hline
\end{tabular}


In its 2013 Corporate Responsibility Report, Delta Air Lines referenced sustainability related information based on GRI G3.1 guidelines (GRI, 2015). Delta Air Lines participated in the 2014 CDP Climate Change and 2014 Supply Chain questionnaires. Delta's disclosure score for the 2014 Climate Change questionnaire was 93 out of 100 possible points. The assessment of Delta's Climate Change questionnaire placed it in performance band B (CDP, 2015).

United Airlines published its sustainability report in accordance with GRI G3 guidelines (GRI, 2015). United Airlines submitted the CDP Climate Change 2014 questionnaire, but did not receive a disclosure score (CDP, 2015).

\section{National carriers}

Only three out of seven national carriers published sustainability reports. These three, Alaska Airlines, jetBlue and Southwest Airlines, participated in the GRI. Southwest Airlines was the only carrier in this group which also participated in the CDP. Alaska Airlines 2013 Sustainability Report referenced sustainability information according to GRI G4 guidelines (GRI, 2015). Alaska Airlines did not participate in any CDP questionnaires (CDP, 2015). JetBlue referenced the GRI G4 index in its 2013 Responsibility Report (jetBlue, 2014). jetBlue did not participate in any CDP questionnaires. As part of its 2013 Southwest Airlines One Report, Southwest used the GRI G3 methodology to index the airline's sustainability disclosures (GRI, 2015). Southwest Airlines also participated in the CDP Climate Change and Supply Chain questionnaires. For the Climate Change 2014 questionnaire, Southwest received 89 out of 100 points on its disclosure score. For performance, Southwest ranked in performance band B (CDP, 2015).

\section{Regional carriers}

SkyWest did not publish a sustainability report nor participated in CDP. Envoy Air, as wholly-owned subsidiary of American Airlines Group, indirectly participated in the CDP.

\section{Cargo carriers}

FedEx and UPS participated in sustainability reporting and submitted one or more CDP questionnaires. Atlas Air and Kalitta Air LLC did not publish sustainability reports and did not participate in the CDP.

In FedEx's 2013 Global Citizenship Report, the GRI G3.1 index was used to identify relevant sustainability disclosures (GRI, 2015). FedEx also participated in the CDP Climate Change and Forests questionnaires. For the Climate Change 2014 questionnaire, FedEx received a disclosure score of 90 out of 100 and was placed in the B performance band (CDP, 2015). 
UPS used the GRI G4 guidelines to index relevant information in its 2013 Sustainability Report (GRI, 2015). UPS submitted answers to the Climate Change, Water and Forests CDP questionnaires. For the 2014 Climate Change questionnaire, UPS received a disclosure score of 100 out of 100 and was placed in the A- performance band.

\section{Discussion}

According to the KPMG 2013 Survey of Corporate Responsibility Reporting, $86 \%$ of the 100 largest U.S. companies by revenue participated in sustainability reporting (KPMG, 2013). Based on the results of this exploratory study, the reporting average among large U.S. carriers was considerably lower at $53 \%$ and it appeared that the aviation sector lagged behind other sectors in sustainability reporting practices.

The Carbon Disclosure Transport Report stated "the Transport sector is behind other industries in terms of environmental impact reporting and goalsetting" (CDP, 2009, p.2). This lack of sustainability reporting was particularly troubling considering that fuel consumption by transportation companies accounted for roughly $50 \%$ of global oil consumption (Finley, 2012).

The low percentage of sustainability reporting among U.S. air carriers might, however, lead to financial improvements. U.S. air carriers might be able to increase their market value or profitability by adopting sustainability reporting practices:

More and more investors accept that environmental and social factors put company value at stake. This leads to the question of what the potential financial impacts of those risks and opportunities could be and what the company is doing to mitigate or maximize them. (KPMG, 2013, p. 13)

According to Lo and Sheu (2007), a significant positive correlation between corporate sustainability practice adoption and market value existed. GRI went one step further, suggesting that sustainability reporting was "a vital step for managing change towards a sustainable global economy - one that combines long term profitability with social justice and environmental protection" (GRI, 2013c, p.8). Kolk (2003) found that in some companies, the implementation of sustainability reporting was helped by "the discovery of economic benefits of sustainability (reporting), ranging from higher efficiencies and lower costs and risks to improved relationships with stakeholders and a better reputation." (p. 290). If these same effects occurred in airlines, an airline may be able to profit from participating in sustainability reporting, making the results of this study a clarion call for change for more sustainability reporting in the aviation industry. 
The results also showed that there were notable differences between the carrier groups. All three U.S. legacy carriers participated in sustainability reporting, while a lower percentage of airlines did so in the national carrier group and the cargo carrier group. Future research could focus on these observed differences and investigate the "why". Why do certain carriers publish sustainability reports and why do others not? Initiatives, such as the CDP, rely on stakeholder influence to convince businesses to publish information related to sustainability aspects. Does this mean that airlines have not yet experienced societal pressure to participate in sustainability reporting? Is the business case for sustainability reporting for airlines the same or different from that of other industry sectors? Why has there been a lag for airlines as compared to other industry sectors? What are the differences in quality of sustainability reporting among airlines? Does quality of reporting have a correlation to market value?

Finally, regulatory pressure has not yet forced airlines to embrace sustainability reporting, a fact which may change in the near future with a pending ruling by the U.S EPA. These and similar hypotheses are worthwhile topics for further research in the area of sustainability reporting.

\section{Limitations and Delimitations}

The findings in this study were based on data reported by CDP and GRI and as such the accuracy of these databases is assumed but ultimately outside of the influence of the researchers. The methodology of the air carrier selection was based on 2013 revenue data as reported to the DOT. It can be assumed that revenues for some of the airlines analyzed in this study have changed since then. As of April 2015, no updated classification of Group III has been provided by the DOT.

The scope of this study was limited to the analysis of GRI and CDP sustainability reporting practices. Within this bounded frame, the quality of sustainability reports as well as participation in other sustainability frameworks was not analyzed. The KPMG 2013 Survey of Corporate Responsibility Reporting, for example, dedicated over half of its report to the qualitative evaluation of sustainability reports (KPMG, 2013). The results for CDP were limited to submissions for the 2014 questionnaires.

Due to the observational nature of the study, the results did not shed light on an airline's motive to participate in sustainability reporting nor on reasons for differences in reporting between the carrier groups.

\section{Conclusion}

Based on the results of this exploratory study, it appeared that the U.S. airline industry has considerable room for improvement in terms of the percent of 
companies involved in sustainability reporting, if the airline industry is to become consistent with global sustainability reporting practices. While all three U.S. legacy carriers, American Airlines, Delta Air Lines and United Airlines participated in sustainability reporting, the percentage dropped considerably among national air carriers, where only about $40 \%$ of all carriers participated in sustainability reporting. For cargo airlines, only two carriers, FedEx and UPS, engaged in sustainability reporting. The only regional carrier in this study, SkyWest, did not publish a sustainability report.

As the nature of exploratory research is based on observing and exploring trends only, this paper did not provide solutions for existing problems in the area of sustainability reporting. The study did show that the absolute percentage of reporting airlines was significantly lower compared to other industries and that there were differences between carrier groups. The authors hope that these findings will open the topic of sustainability and more specifically, sustainability reporting, up for discussion in the academic community and that more research in this area will follow.

This research addressed the question of which US air carriers report sustainability. The result was that the air carriers in this study lag behind in percentage of airlines participating in sustainability reporting, as compared to the 4,100 largest companies by revenue worldwide. Once the decision is made to include sustainability reporting as a standard business practice, then three questions may be useful for future research and discussion: what should be reported, how should it be reported and how can the process of reporting be used to create a competitive advantage and to maximize shareholder and stakeholder value? (KPMG, 2013). Future research is necessary to investigate qualitative differences between the sustainability reports published by airlines, as even a preliminary look by the researchers at the publications suggests wide disparities. Additionally, this study has shown that there are noticeable differences between carrier groups. Future research could investigate why these disparities exist. Future research studies may also investigate some of the best practice examples of airlines participating in sustainability reporting to shed light on their motivation to do so. 


\section{References}

Air Transport Action Group. (2014). Aviation: Benefits beyond borders. Retrieved from http://aviationbenefits.org/media/26786/ATAG_AviationBenefits20 14_FULL_LowRes.pdf

American Airlines Group. (2013). 2012 Corporate Responsibility Report. Retrieved from http://www.aa.com/content/images/production/corporateresponsibility/2013/2012_Corporate_Responsibility_Report.pdf

Carbon Disclosure Project. (2010). Carbon Disclosure Project Transport Report. Retrieved from https://www.cdproject.net/CDPResults/CDP-TransportReport.pdf

Carbon Disclosure Project. (2014). CDP the facts. Retrieved from https://www.cdp.net/Documents/CDP-the-facts.pdf

Carbon Disclosure Project. (2015). Company responses. Retrieved from https://www.cdp.net/en-US/Respond/Pages/companies.aspx

Delbard, O. (2008). CSR legislation in France and the European regulatory paradox: An analysis of EU CSR policy and sustainability reporting practice. Corporate Governance: The international journal of business in society, 8(4), 397-405. http://dx.doi.org/10.1108/14720700810899149

Elkington, J. (1997). Cannibals with forks: The triple bottom line of the 21st century. Oxford, UK: Capstone.

Finley, M. (2012). The oil market to 2030: Implications for investment and policy. Economics of Energy \& Environmental Policy, 1(1), 25-36. http://dx.doi.org/10.5547/2160-5890.1.1.4

Frost, G., Jones, S., Loftus, J. \& Van Der Laan, S. (2005). A survey of sustainability reporting practices of Australian reporting entities. Australian Accounting Review, 15(35), 89-96. doi:10.1111/j.18352561.2005.tb00256.x

Global Reporting Initiative. (2013a). G4 sustainability reporting guidelines. Retrieved from https://www.globalreporting.org/resourcelibrary/GRIG4Part1-Reporting-Principles-and-Standard-Disclosures.pdf

Global Reporting Initiative. (2013b). Sustainability topics for sectors: What do stakeholders want to know? Retrieved from https://www.globalreporting.org/resourcelibrary/27-Airlines.pdf 
Global Reporting Initiative. (2013c). Carrots and sticks - sustainability reporting policies worldwide -today's best practice, tomorrow's trends. Retrieved from https://www.globalreporting.org/resourcelibrary/Carrots-andSticks.pdf

Global Reporting Initiative. (2014). Linking GRI and CDP. Retrieved from https://www.globalreporting.org/resourcelibrary/Linking-GRI-and-CDP2014.pdf.

Global Reporting Initiative. (2015a). About us. Retrieved from https://www.globalreporting.org/information/about-gri/what-isGRI/Pages/default.aspx

Global Reporting Initiative. (2015b). GRI reports list (Limited) - 31.03.2015 [Data file]. Retrieved from https://www.globalreporting.org/resourcelibrary/GRI-Reports-List-19992015.zip

GreenBiz. (2013). Why CDP, GRI, DJSI stand out among sustainability frameworks. Retrieved from http://www.greenbiz.com/blog/2013/08/19/why-cdp-gri-djsi-stand-outamong-sustainability-frameworks

Intergovernmental Panel on Climate Change. (1999). Aviation and the global atmosphere: Summary for policymakers. Retrieved from https://www.ipcc.ch/pdf/special-reports/spm/av-en.pdf

Jaeger, R. G., \& Halliday, T. R. (1998). On confirmatory versus exploratory research. Herpetologica, 54. Retrieved from http://www.jstor.org/stable/3893289

Janić, M. (2007). The sustainability of air transportation: A quantitative analysis and assessment. Hampshire, England: Ashgate Publishing, Ltd.

JetBlue. (2014). 2013 responsibility report. Retrieved from http://www.jetblue.com/p/JetBlueResponsibilityReport2013.pdf

Johnson, M. E. \& Gonzalez, A. (2013). Effects of a carbon emissions trading system on aviation financial decisions. Journal of Aviation Technology and Engineering, 2(2). http://dx.doi.org/10.7771/2159-6670.1073

Kolk, A. (2003). Trends in sustainability reporting by the Fortune Global 250. Business Strategy and the Environment, 12(5), 279-291. doi:10.1002/bse.370 
Kolk, A. (2004). A decade of sustainability reporting: Developments and significance. International Journal of Environment and Sustainable Development, 3(1), 51-64. doi:10.1504/IJESD.2004.004688

Kolk, A. (2008). Sustainability, accountability and corporate governance: Exploring multinationals' reporting practices. Business Strategy and the Environment, 17(1), 1-15. doi:10.1002/bse.511

KPMG. (2013). The KPMG survey of corporate responsibility reporting 2013. Retrieved from http://www.kpmg.com/Global/en/IssuesAndInsights/ ArticlesPublications/corporate-responsibility/Documents/corporateresponsibility-reporting-survey-2013-v2.pdf

Lo, S.-F. \& Sheu, H.-J. (2007). Is corporate sustainability a value-increasing strategy for business?. Corporate Governance: An International Review, 15(2), 345-358. doi:10.1111/j.1467-8683.2007.00565.x

Milne, M. J., \& Gray, R. (2013). W (h) ither ecology? The triple bottom line, the global reporting initiative, and corporate sustainability reporting. Journal of Business Ethics, 118(1), 13-29. http://dx.doi.org/10.1007/s10551-0121543-8

Saiyid, A. (2015, May 22). Final Greenhouse Gas Regulations for Power Plants Due Out in August, EPA Agenda Says. Bloomberg BNA. Retrieved from http://www.bna.com/final-greenhouse-gas-n17179926997/

Stebbins, R. A. (2001). Exploratory research in the social sciences. Thousand Oaks, CA: Sage.

U.S. Department of Transportation. (2013). Air carrier groupings. Retrieved from http://www.rita.dot.gov/bts/sites/rita.dot.gov.bts/files/Directive_309.pdf

U.S. Department of Transportation. (2015). Airline fuel cost and consumption [Data file]. Available from http://www.transtats.bts.gov/fuel.asp?pn=1

U.S. Environmental Protection Agency. (n.d.). Endangerment and cause or contribute findings for greenhouse gases under Section 202(a) of the Clean Air Act. Retrieved from http://www.epa.gov/climatechange/endangerment

U.S. Federal Aviation Administration. (2015a). NextGen portfolios. Retrieved from https://www.faa.gov/nextgen/snapshots/portfolios/

U.S. Federal Aviation Administration. (2015b). Performance: National Airspace System. Retrieved from https://www.faa.gov/nextgen/snapshots/nas/ 
Rudari and Johnson: Sustainability Reporting Practices of Group III U.S. Air Carriers

Upham, P. (Ed.). (2003). Towards sustainable aviation. London, UK: Earthscan 